\title{
THE GENERAL PRINCIPLES OF FAMILY LAW IN ISLAMIC STATES
}

\section{Mendzhul M. V.}

\section{INTRODUCTION}

Globalization processes led to the rapprochement of different legal systems. At the same time, growing migratory processes over the recent years and the increase of the number of Muslims in Europe revealed many problems and collisions in the legal regulation of family relationships as well as in the politics of multiculturalism. The topicality of studying the principles of family law in Islamic states is caused by the fact that more often than not there are cases when courts in the EU countries analyze the diversity and religious pluralism. The requirements of the Shariah became the subject of analysing such issues as wearing a scarf, hijabs in educational establishments, at work, the existence of arranged and forced marriages, the recognition of polygamous marriages and the consequences of the international talaq (repudiation refers to the husband's right to dissolve the marriage by simply announcing to his wife that he repudiates her), etc. Undoubtedly, courts in the European States study such cases according to the norms of the national law, and at the same time through the prism of international private law and respect to the human rights; the norms of personal law as well as the ones of the Shariah, are taken into account.

\section{The Reforming of Family Law in Islamic States}

Islam is not only one of the most widespread religions in the world, but it is also recognized as the state religion in many countries and is the basis for regulating Muslim family relations. More than $88 \%$ of the population in Indonesia are Muslims, over 90\% of Muslims live in Bangladesh, Egypt, the Niger, Pakistan, Sudan, Syria, Uzbekistan, from $97 \%$ to $99 \%$ of the population in Algeria, Afghanistan, Iran, Iraq, Yemen, Morocco, Turkey and Saudi Arabia are Muslims. Even in the modern legislation of Muslim countries when a legal norm is absent or while interpreting law, reference is made to the principles of law, the provisions of the Koran and the works of authoritative Muslim lawyers.

At the moment, in states where the overwhelming majority of the population practise Islam, there are three models of state-religious relations: 1) under the first model, Islam is legally recognized as the state religion, yet a special place in the legislation as well as the administration of law and justice is held by the shariah (Algeria, Bahrain, Egypt, Iraq, Jordan, Kuwait, 
Libya, Mauritania, Morocco, Oman, Palestine, Qatar, Saudi Arabia, Tunisia, the United Arab Emirates, Yemen, Bangladesh, Brunei, Iran, Malaysia, Maldives, Pakistan, Afghanistan and Somalia); 2) according to the second model Islam is not formally recognized as the state religion, but private law that applies to Muslims is usually based on the Shariah (Indonesia and Nigeria); 3) under the third model, there is no legally recognized religion, and accordingly, religious norms, including the Shariah, do not apply (Bosnia and Herzegovina, Kazakhstan, Kyrgyzstan, Tajikistan, Turkey, Turkmenistan and Uzbekistan, Albania and Azerbaijan) ${ }^{1}$.

The features of legal culture in Islamic states, the sources of Muslim law were analyzed by Nakhla Youssef ${ }^{2}$, M. A. Voronina ${ }^{3}$ and others. The reforming of Muslim Law in the $19^{\text {th }}$ and $20^{\text {th }}$ centuries, including changes in the principles of regulating family relations, were investigated by V. Kushnirenko ${ }^{4}$, V. I. Lubskyi, T. H. Horbachenko, M. V. Lubska ${ }^{5}$, Kristen Stilt, Salma Vaheedi, Swathi Gandhavadi Griffin ${ }^{6}$, Lama Abu-Odeh ${ }^{7}$, Zainah Anwar, Yana S. Rumminger ${ }^{8}$, Mounira M. Harrad ${ }^{9}$, Jawaid Rehman ${ }^{10}$ and others.

A number of Islamic scholars, in particular, such as Mohamed Abdu, Abdel Aziz Taalbi, Jamal Al-Din Al-Afghani, Ibn Abi Al Diaf, Khair Al-Din Bach, Rifa'a Al Tahtawi, were convinced that one of the reasons for the socio-economic backwardness of Muslim States is the inferior status of women. They promoted liberal ideas related to the fact that the Prophet Muhammad's wives were able to read, write and even discuss business agreements, meanwhile defending Islamic norms, in particular by referring to the provisions of the Koran. At the end of the $19^{\text {th }}$ century, Qasim Amin

${ }^{1}$ Aayesha Rafiq. Child Custody in Classical Islamic Law and Laws of Contemporary Muslim World (An Analysis). International Journal of Humanities and Social Science. Vol. 4 No. 5, March 2014. http://www.ijhssnet.com/journals/Vol_4_No_5_March_2014/29.pdf. 267-268.

${ }^{2}$ Нахла Юсеф, Особливості правової культури країн Близького Сходу. Політичний менеджмент. 2009. № 1.150.

${ }^{3}$ М.А. Вороніна. Взаємодія традиційного права країн Африки з ісламським правом Державне будівництво та місиеве самоврядування. 2012. Випуск 24. С. 52.

${ }^{4}$ Володимир Кушніренко. Ісламське суспільство та його вестернізація. Політичний менеджмент. 2003. № 1. С. 137-138.

5 Лубський B.I., Горбаченко Т.Г., Лубська М.В. Мусульманське сімейне право: релігієзнавчо-правовий контекст. Одеса.: «Інтерпринт», 2010. 410 с.

${ }^{6}$ Kristen Stilt, Salma Waheedi, Swathi Gandhavadi Griffin. The Ambitions of Muslim Family Law Reform. Harvard Journal of Law \& Gender. 2018. Vol. 41. P. 305.

${ }^{7}$ Lama Abu-Odeh. Modernizing Muslim Family Law: The Case of Egypt. Vanderbilt Journal of Transnational Law 2004. VOL. 37:1043. H. 1131.

${ }^{8}$ Zainah Anwar and Jana S. Rumminger,Justice and Equality in Muslim Family Laws: Challenges, Possibilities and Strategies for Reform. Wash. \& LeeL. 2007. 64. H. 1547.

${ }^{9}$ Mounira M. Charrad. Tunisia at the Forefront of the Arab World: Two Waves of Gender Legislation. WASH. \& LEEL. REV. 2007. 64. P. 1523.

${ }^{10}$ Javaid Rehman. The Sharia, Islamic Family Laws and International Human Rights Law: Examining the Theory and Practice of Polygamy and Talaq. International Journal of Law, Policy and the Family 21,(2007), p. 117 doi:10.1093/lawfam/eb1023

168 
published the book «The Liberation of Women» (1899), which became the impetus for the protection of women's rights not only in Egypt, but throughout the Arab Muslim world. In his book, he argued that women's access to education and socio-economic opportunities is an important first step towards modernizing Arab societies ${ }^{11}$. Qasim Amin notes that it was the «Islamic legal system, Shariah, that guaranteed the equality of women and men, compared with any other legal system of that time. Islam granted women rights to buy-sell relationship, charity, custody, the disposal of property, unhindered demand for permission from father or husband». Continuing to adhere to his revolutionary position at that time, Amin claimed that divorce was not a haraam (a sin) and was quite acceptable in Islam, arguing that it was necessary to give women the right to initiate a divorce, which will provide them with fairer and more humane conditions.

In the same period (the 1900s), Abdelaziz Taalbi, along with other scholars, published the book «The Liberal Spirit of the Quran», in which they drew attention to the problem of educating girls and opposed women's living a solitary life which, in their opinion, impeded social progress. All these new ideas on the status of women in Tunisia created a liberal atmosphere; this aroused interest among scientists, and led to the publishing of a number of scientific articles and works. A significant contribution was made by Tahar Haddad, who vehemently defended the position that Islam enhanced the status of women compared to pre-Islamic period. His main ideas were set forth in the book "Our Women in the Sharia and in Society» (1930). It was justified there that Islam granted women a significant range of rights Haddad also believed that oppression of women in the case with Tunisian society had been embedded in the patriarchal system. However, such revolutionary views at that time caused a lot of criticism.

It is traditionally accepted in the doctrine of law to distinguish four main sources of Muslim law: the Koran, the Sunnah, Ijma and Qiyas. The historical analysis allows us to conclude that the Koran was quite progressive for its time in regulating family relations. Indeed, in pre-Islamic Arabia, women had a status similar to slaves, they were not recognized as subjects of relations and, like movable things, were sold by the elders on behalf of the clan. The instantaneous and unreasonable talaq («repudiation», in its modern meaning, divorce) was a common and widespread practice, as well as unlimited polygamy. Hence, it was established by the Koran that a woman is a subject of relations, limited polygamy (up to four wives). Unlike the Koran, which contains the thoughts and sayings of Mohammed (or Muhammad), the Sunna is a collection of the practices and sayings of the prophet described by theologians and lawyers known at that time $\left(7^{\text {th }}-9^{\text {th }}\right.$ cent. $)$.

\footnotetext{
${ }^{11}$ Khedher, Rayed (2017). Tracing the Development of the Tunisian 1956 Code of Personal Status. Journal of International Women's Studies. 18(4), p. 31.
} 
The codification of the Shariah in Sunni Islam was carried out mainly by four lawyers, in particular: Abu Hanifa, Malak Ibn Anas, Muhammad Ibn Idris al-Shafi and Ahmad Khanbal. If there were no specific answers in the Koran and the Sunna, Muslim lawyers were looking for similar situations in which a certain decision was made, and in this process they were relying on a number of secondary sources, including Ijma and Qiyas. Ijma, which means «consensus», is an important secondary source that provided the Islamic community with the necessary tools to reach an agreement and created a powerful methodology in interpreting the Koran and Sunnah ${ }^{12}$. Muslim lawyers also apply judgments by analogy (Qiyas), the essence of which is to form a conclusion on the case on the basis of a previously adopted rule (decision) on a similar case, which allows us to solve the problem by means of combining «divine revelation with human thinking» ${ }^{13}$.

In general, only in the $20^{\text {th }}$ century, in most Islamic states, the reform of family law took place and special legislative acts were adopted. The beginning of this process is associated with the adoption of the Majallah in 1869 - 1877, which was operating in most Arab states that were part of the Ottoman Empire, except Egypt. This act regulated issues of legal capacity and its limitations, however, it did not concern family relations. Around the same period, Muhammad Kadri Pasha in Egypt made a serious attempt to codify the right of personal status, he prepared «Shariah Norms on Personal Status». This project was not put into effect as an official law, but was actually applied in Egypt until the 1920s. The Civil Code of the Arab Republic of Egypt entered into force on October 15, 1949, and it regulates family relations in combination with the norms of special laws and Islam. Almost until the middle of the $20^{\text {th }}$ century family law in most Muslim states remained generally uncodified ${ }^{14}$.

In Tunisia, as early as 1956, a new law on personal status (also translated as a code), was adopted, it granted women equal rights to divorce men, established the principle of voluntary marriage, obliging both parties to consent to marriage (articles 5 and 9), abolished polygamy (article 18) and granted women equal rights with men to work, move, open bank accounts.

The most significant family law reform in Pakistan in recent decades was the Muslim Family Law Ordinance of 1961, based on the 1956 report from the Marriage and the Family Law Commission. The reform was taking place

${ }^{12}$ Javaid Rehman. The Sharia, Islamic Family Laws and International Human Rights Law: Examining the Theory and Practice of Polygamy and Talaq. International Journal of Law, Policy and the Family. 2007. 21, p. 112.

${ }_{13}$ Чепульченко Т.О. Особливості правового регулювання в країнах релігійного права. Вісник НТУУ «КПІ». Політологія. Соціологія. Право. Випуск 1(21). 2014. С. 118.

14 Лубська М.В. Загальні аспекти реформування мусульманського шлюбно-сімейного права у контексті визнання правового статусу особи в державах ісламської традиції. Вісник НАУ. Серія: Філософія. Культурологія. 2010. № 2 (12). С. 126-127. 
in the confrontation between modernists and supporters of the secular approach. Associations such as the Pakistan Women's Association and the United Front for Women's Rights supported the reform and, in the late 1950s and early 1960s, actively advocated for the expansion of women's rights in marriage, during the divorce process and inheritance procedure. Among the Commission's proposals was the establishment of the simplified procedure (not general civil procedure) for considering family disputes. It was proposed to establish that the trial cannot exceed three months, and the decision of the family court could not be reviewed. The court had to be vested with great discretionary powers to regulate the proceedings in accordance with the circumstances of each case. The recommendations of the Commission were immediately implemented. Only in 1996, it was established by law that the term for considering divorce cases may not exceed 4 months.

Some scholars argue that the Muslim Family Law Ordinance of 1961 is Pakistan's most definitive step in giving women and men equality in rights, while others point to the weakness of the reform and the fact that there were made the significant concessions to traditionalists ${ }^{15}$.

In 2000, in the Arab Republic of Egypt the Personal Status Law was substantially amended, granting women the right to establish the terms of a marriage contract linked to the right to divorce in case of a man's other marriage. Further reforms in 2005 also included the establishment of family courts, a family fund which provides alimony payments to support women, and reformed approaches to child custody ${ }^{16}$.

In 2004, in Morocco, there were introduced fairly progressive norms as a result of the reform of family law. Mudawana (the name of the Moroccan family code), is based on the Maliki Islamic Law School, codified in 19571958, after Morocco gained independence from France. Mudawana, as amended in 1958, provided for unlimited polygamy (up to four wives), unilateral termination of a marriage by a husband for no reason, and the dependent position of a woman on a man. Since the 1980s, the movement for women's rights and the promotion of equality in family relations had intensified in Morocco. In 1992, a women's rights group launched the One Million Signatures Campaign, which aimed to collect signatures for a petition to reform Mudawana. The campaign was quite successful, as a result it was an impetus for the creation of a working group on reforming the family code, and in October 2003 the project was submitted to the Moroccan parliament. According to the new Moroccan family code of 2004, spouses have equal family rights, a husband's guardship over the wife has been

${ }^{15}$ Haider Nadya. Islamic Legal Reform: The Case of Pakistan and Family Law. Yale Journal of Law \& Feminism. 2000. Vol. 12: Iss. 2, 287-341. P. 298-308.

${ }^{16}$ Camilo Gómez-Rivas. Women, Shari‘a, and Personal Status Law Reform in Egypt after the Revolution. October 1, 2011. URL: https://www.mei.edu/publications/women-sharia-andpersonal-status-law-reform-egypt-after-revolution. 
eliminated, the marriage age has increased, women are given the right to conclude a marriage contract on their own, the husband's right to unilateral rejection of marriage has been cancelled, women's rights to inheritance and property have been expanded, children born out of wedlock are recognized, polygamy was not eliminated, but it was limited.

Iranian women played an important role in the Persian Constitutional (conditional) Revolution of 1905-1911, which led to the formation of the first parliament in Iran. Women were involved in public affairs after this event and were engaged in journalism, education, etc. Among the prominent Iranian women who played an important role in the revolution, there was even the first woman in the first parliament - Bibi Khatun Istrabadi. In 1907, the first women's magazine «Danesh» was published, as well as other publications in various regions. During 1921-1925 there was a period of narrowing women's rights, the closure of women's magazines. After the White Revolution of 1962, a law was passed granting women the right to vote. The Family Protection Act of 1967, banned an extrajudicial divorce, limited polygamy and envisaged the establishment of family courts. Unfortunately, the Family Protection Act of 1975 was a step backward in terms of ensuring women's rights. And after the revolution in 1979 and the creation of the Islamic Republic of Iran, women's rights were significantly limited, both Muslims and non-Muslims were obliged to wear the hijab. There was ensured accountability in the form of 70 lashes or 60 days of imprisonment for violating the obligation to wear the hijab. Women were forbidden to work in the judicial system, they were forbidden to play sports with men.

In the early 1990s, there was an increase in the level of education of women and their employment in various sectors of the economy. In 2006, women made up more than half of university students in Iran; their percentage in science and technology was more than 70\%. In 2012, in Iran there was taken a decision to prevent girls from choosing a specialty. The Nobel Peace Prize laureate and human rights activist Shirin Ebadi appealed to the Executive Director and Under-Secretary-General of the United Nations for Gender Equality and Empowerment to stress the fact that this is a new type of discrimination against Iranian women. As a result of this policy, girls could not choose specialties in the fields of computer science, chemical engineering, industrial engineering, civil engineering, mechanical engineering, agricultural engineering and chemistry, political science, accounting, business administration, electrical engineering, etc. In 2008, on the initiative of the President of Iran, a draft law on family support was submitted to the parliament, which allowed a man to marry his second wife without his first wife's permission and establish financial restrictions for women. The parliament rejected the bill. Thus, now in Iran it is difficult to talk about the equality of men and women; even the positive practices at the beginning of 
the $20^{\text {th }}$ century are already part of the history of rule-making, and by no means, of reality.

In 2005, family law was reformed and in Algeria, in particular, women's right to divorce was granted, polygamy was limited, but there was no real adoption of the principle of equality.

Sudan is an example of a state that has not yet implemented family law reform. The law on the personal status of Muslims, adopted in Sudan in 1991, caused a lot of criticism because it legalized child marriage, provided for the full custody of the husband over his wife (qawama principle), including the provision of work permit. In 2006, the National Committee to review the status of women in legislation (the First National Committee) was established to review all Sudanese laws in the light of the Constitution of 2005. In 2009, the National Committee identified 88 articles in the laws that need to be reformed to ensure gender equality, yet aiming to abolish the guardianship of men over women, raise the minimum marriage age up to 18 years old, recognize the paternity of children born out of wedlock and others, which unfortunately were never accepted. ${ }^{17}$ Women's human rights organizations in Islamic states continue to support the reform of Muslim family laws based on the principles of equality and justice.

Currently, family relations in Muslim states are regulated not only by religious norms, but also by normative acts. For example, the Turkish Civil Code was adopted on November 22, 2001 (entered into force on January 1, 2002) consists of five books, of which the second is devoted to family law. In Pakistan, the sources of family law are the Law on the Muslim Personal Law (Shariat) Application (1935), the Law on the Muslim Law (Shariat) Application (1937), the Law on the Application of Muslim Law in Western Punjab (Shariat) (1948), The Child Marriage Restraint Act (1929), The Dissolution of Muslim Marriages Act (1939), The Dowry and Bridal Gifts (Restriction) Act (1976), The Guardians and Wards Act (1890), The Family Courts Act (1964), The Muslim Family Laws Ordinance (1961), The West Pakistan Family Court Rules (1965) and others.

Hence, at present, family relationships in the Muslim law are regulated by the Personal Status Law and in the majority of Muslim states there is special legislation, which regulates either civil and family relations (The Civil Code) in general or only family relations, or certain institutions of family law (special laws); such laws quite frequently contain the norms of the Inheritance Law.

${ }^{17}$ Samia El Nagar, Liv Tønnessen. Family law reform in Sudan: Competing claims for gender justice between sharia and women's human rights. CMI report, number 5, December, 2017. URL: https://www.cmi.no/publications/file/6401-family-law-reform-in. 


\section{Basic principles of family law of Islamic states}

At the constitutional level, Muslim states have enshrined the principles of family law, in particular: equality (Art. 4, Art. 9 of the Constitution of the Arab Republic of Egypt, Art. 21 of the Tunisian Constitution, Art. 10 of the Constitution of the Republic of Turkey, Art. 14 and Art. 16 of the Constitution of Iraq, Art. 20 of the Iranian Constitution, Articles 14 and 25 of the Constitution of the United Arab Emirates', Article 41 of the Constitution of Yemen, Article 25 of the Constitution of Pakistan, Article 32 of the Constitution of Algeria), justice (Art. 4 of the Constitution of the Arab Republic of Egypt), the prohibition of discrimination (Art. 53 of the Constitution of the Arab Republic of Egypt, Art. 10 of the Constitution of the Republic of Turkey), equality between men and women (Art. 11 of the Arab Republic of Egypt, Art. 19 of Morocco's Constitution, Art. 46 of the Tunisian Constitution, Art. 36 of the Constitution of Algeria), counteraction to domestic violence (Art. 11 of the Constitution of the Arab Republic of Egypt, Art. 72 of the Constitution of Iraq, Art. 29 of the Tunisian Constitution, Art. 41 of the Constitution of the Republic of Turkey), state protection of the family (Art. 72 of the Constitution of Algeria, Art. 15 of the Constitution of the United Arab Emirates, Art. 26 of the Constitution of Yemen, Art. 35 of the Constitution of Pakistan, Art. 21 of the Constitution of Iran, Art. 29 of the Constitution of Iraq), the protection of private and personal life (Art. 57 of the Constitution, Art. 24 of the Constitution of Morocco, Art. 24 of the Constitution of Tunisia, Art. 20 of the Constitution of the Republic of Iraq, Art. 17 of the Constitution of Iraq), welfare of the family (Art. 41 of the Constitution of Turkey Republic), the best interests of the child (Art. 80 of the Constitution the Arab Republic of Egypt, Art. 47 of the Tunisian Constitution), and the upbringing of children in accordance with Islam (Art. 9 of The Constitutional Decree of the Saudi Arabia).

In Muslim states, there is are different approaches to understanding the concept of marriage. According to Art. 4 of the Morocco Marriage Code, marriage is a mutual agreement and legal relationship between a man and a woman on a permanent basis to protect the family and create a stable family in accordance with the provisions of this code. Indonesia's Marriage Act (1974) in Art. 1 defines marriage as a physical bond between a man and a woman as husband and wife in order to form a happy and eternal family on the basis of the Sole God. According to Art. 3 of Iraq's Personal Status Law of 1959, marriage is a contract between a man and a woman which is legally permitted, the purpose of which is bonding, cohabitation and having children.

There are certain conditions for getting married in all Muslim states, first of all, marriageable age. Since marriage age is not defined in the Koran, it is set differently in Islamic states. In 2004, the age of 18 was set as the marriage age in Morocco, for both men and women. Similarly, the Egyptian legislation was amended in 2008 and the marriage age of 18 was set as appropriate for both 
the bride and the groom. The Jordanian Family Law (2010) set 18 as the marriageable age. In 2005 Algeria set the minimum age of 19 for getting married. Admittedly, the marriage age for men in Bangladesh is 21, Indonesia - 19 years, Syria, Iraq, Tunisia, Turkey, Lebanon, Pakistan - 18, Kuwait - 17, for women in Bangladesh, Tunisia, Iraq and Morocco - 18, Malaysia, Turkey, Syria and Lebanon - 17, Pakistan - 16, Kuwait -15. In countries where the minimum marriage age for girls has been raised, a marriage can be concluded before the marriage age is reached provided there is the court's order as well as the legal guardians' consent (for example, in Turkey for those aged 16, Jordan, Iraq and Morocco - 15).

In spite of the positive examples in some Muslim states, where the equal approach regarding the marriage age for both fiances and fiancees has been established (Algeria, Morocco, Egypt, Jordan), most Islamic states have the opposite situation, and moreover, child marriage is essentially allowed.

In this context, Iran is not an exception. Here the marriage age for men is 15 and for girls $-13^{18}$. Iran ratified the Convention on the Rights of the Child in 1994, which sets 18 years old as the minimum marriage age, but with the caveat, which allowed the national law to remain unchanged. According to the Civil Code of Iran in 2007, marriage is «forbidden» unless the age is reached. However, the legal age of majority is 9 lunar months (8 years and 9 months) for girls and 15 months for boys. Back in 2014, Iran pledged to study recommendations related to repealing the laws that allowed child marriage and amend the Civil Code so that it might be possible to set 18 years old as the minimum marriage age. However, at this point, the issue is not resolved, and girls in Iran can get married at the age of 13, and they can marry from the age of 9 if there is the permission of their parents and the court. According to the statistics, in Iran 17\% of girls under 18 are married and 3\% of girls are married under 15. The UN Special Rapporteur on the Human Rights Situation in Iran said that in 2012-2013 there were registered about 40,635 marriages of girls under 15, of which more than 8,000 marriages were the ones where men were over 10 years older than their women ${ }^{19}$. According to the statistics of the UNICEF for 2018, 17 percent of Iranian girls are married under the age of $18^{20}$.

In Saudi Arabia, the marriage age is not legally defined and the media continue to periodically report on child marriages, even with girls under the age of 8. In January 2019, there was made a proposal to set 18 as the

${ }^{18}$ Best Practices. Progressive Family Laws in Muslim Countries. August 2005. p. 8. URL: https://www.wilsoncenter.org/sites/default/files/Best\%20Practices\%20\%28English\%29.pdf.

${ }^{19}$ What's the child marriage rate? How big of an issue is child marriage? URL: https://www.girlsnotbrides.org/child-marriage/iran/.

${ }^{20}$ Patrick Goodenough. Iran Won’t Outlaw Marriage of Under-13 Girls, as Islamic Countries Fare Worst in Annual Gender Survey. URL: https://www.cnsne.ws.com/news/article/patrickgoodenough/iran-wont-outlaw-marriage-under-13-girls-islamic-countries-fare. 
minimum marriage age and given there was the court order - 15; however, it has not been adopted so far.

The authoress has analyzed the principle of equality in Muslim states in a separate article ${ }^{21}$.

As for the principle of voluntary marriage, Islam clearly requires the consent of the bride and the groom, but it is traditionally accepted that parents arrange marriages, they search and select the future bride and groom. In addition, in most Muslim countries, there is the institution of guardianship over women. According to the Koran, the father (another closest relative of the male gender) is the guardian of the girl, and he selects the bridegroom, also gives his consent to the marriage, discusses the terms of the marriage contract, etc. For example, in Morocco, Turkey and Tunisia, the consent of legal guardians is required to marry the one who is under the age. Indonesia's Marriage Law states that a person must obtain consent to marriage from both parents before the age of $21^{22}$. In Saudi Arabia, the consent of the guardian is required for marriage. According to Art. 18 of the Algerian Family Code, a marriage concluded without a guardian or two witnesses must be declared invalid prior to its actual commencement. In our view, the institution of guardianship over women is the evident violation of the equality principle.

In some Muslim states, forced marriages are criminalized. Article 9 of the Iraqi Personal Status Act establishes that no relative or third person can force any person (a man or a woman) to marry without their consent. Forced marriages are considered invalid if the marriage has not been completed. Relatives or third parties cannot prevent the marriage of eligible persons. In case this norm of law has been violated, it gives rise to liability in the form of imprisonment for a term of up to three years and / or a fine, if the offender is a relative of the first degree, if not, then up to ten years of imprisonment. However, in most Islamic states, the practice of coercion to marry by parents and relatives of the bride and the groom is widespread. In Pakistan, forced marriages are still used as a means of reconciliation of families and tribes, it is certainly illegal and can be appealed in court, but there are not many such cases.

The Koran has established a ban on marrying those women who were married to their fathers (4:22), as well as mothers, daughters, sisters, paternal and maternal aunts, daughters of a brother and a sister, mothers who were breast-feeding, breast-feeding sisters , mothers of wives, adopted daughter, wives of sons, or two sisters (4:23), married women (4:24).

${ }^{21}$ Менджул М. В. Принцип рівності та сімейне право ісламських держав. Visegrad Journal on Human Rights. 2019. № . 4. Vol. 1. P. 70-75.

${ }^{22}$ Syahril Jamil. Konstruksi Hukum Keluarga Islam Di Indonesia. Jurnal Usrah. Vol. 3 No. 1, Juni 2017. P. 70. 
In September 2017, Tunisia lifted a ban on Muslim women's marrying to non-Muslim men. This discriminatory legislative provision was part of a series of circulars issued by the Ministry of Justice in 1973. In accordance to Art. 65 of the Family Code of Morocco, Family Court grants permission: to marry a person under the age, to conclude another marriage (polygamy), to marry a person with a mental illness that has led to disability, for the marriage between a Muslim and a foreigner.

Such principle of family law as monogamy is important for European states, and it is common knowledge that Islam tolerates polygamy.

Polygamy is based on the norms of the Koran (4: 3) and is not limitless. First of all, it is possible to have up to four wives at the same time, and in most Islamic states at the level of law it is determined that the right to remarry is granted by the court, when the consent of the first wife is provided, the second wife should be informed of the fact that her future husband has the first wife, and the husband must guarantee fair treatment of all wives.

Among Muslim researchers there has been still a heated debate about the fact whether polygamy is prohibited, except where the protection of orphans' rights is the main objective cause ${ }^{23}$ Many scholars have argued that the Koran's norms of polygamy were adopted in such a historical context when multiple wars resulted in a disproportion between men and women, thus in order to protect the rights of widows and orphans, men were allowed to have up to four wives.

The Family Law Commission in Pakistan noted that «if this way of solving the problem leads to injustice in family relations, then Muslims are advised to practise monogamy only». In its report, the Commission states that a marriage license, allowing one to have more than one wife, established social justice at the time it was written, i. e. in the $7^{\text {th }}$ century. Similarly, regulating the practices will enable us to set the modernist goal of social justice today ${ }^{24} /$

Article 3 of the Indonesian Marriage Law stipulates, on the one hand, that in marriage a husband can only have a wife and a woman - only a husband (part one), on the other hand, in part two, it is stated that courts may grant a husband permission to have more than one wife at the stakeholders' will. In 2007, the Indonesian Constitutional Court was considering the petition linked to lifting restrictions on polygamy and, in its decision, upheld the existing law on the grounds that «its norms aimed at protecting the fundamental rights of existing and future women».

Among Muslim states, polygamy is banned only in Tunisia and Turkey. Thus, justifying the prohibition of polygamy, Article 18 of the Tunisian

\footnotetext{
${ }^{23}$ Nadya Haider. Islamic Legal Reform: The Case of Pakistan andFamily Law. Yale Journal of Law \& Feminism: Vol. 12: Iss. 2.Article 5. P. 311.

${ }^{24}$ Ibid. P. 312.
} 
Law on Personal Status (1956) used the argument that actual «fair treatment» cannot be guaranteed to all wives. For the violation of the polygamy ban there comes the responsibility for both the man and the woman in the form of a year of imprisonment or a fine of two hundred and forty thousand Tunisian francs.

In Islamic states, a marriage contract may limit polygamy (there is a rule that a husband will no longer marry another wife), grant a woman the right to divorce without any cause specified by law, prohibits the husband from restricting his wife's employment and traveling abroad. However, because of traditions and religious norms, women rarely use such opportunities in marriage contracts.

Notwithstanding the prevailing principle of polygamy, in Islamic states, the number of monogamous families has been increasing, one of the reasons is the material one, - most Muslim men are unable to provide equal financial support and create equal conditions for more than one wife. In countries such as Tunisia, the Arab Republic of Egypt, Jordan, Turkey, etc., the situation when both spouses work, is becoming more prevalent.

\section{CONCLUSIONS}

Thus, Muslim states, according to the ratio of religious and legal regulation of family relations can be divided into the following groups: 1) states where family relations are regulated by the laws as well as norms of Islam, but the latter are given priority, including in the administration of justice (Algeria, Bahrain , Egypt, Iraq, Jordan, Kuwait, Libya, Mauritania, Morocco, Oman, Palestine, Qatar, Saudi Arabia, Tunisia, UAE, Yemen, Bangladesh, Brunei, Iran, Malaysia, Maldives, Pakistan, Afghanistan and Somalia); 2) states where Islam is not recognized as a state religion but widely used in the regulation of family relations (Indonesia and Nigeria); 3) states where Muslims predominate but family relations are regulated solely by law (Kazakhstan, Kyrgyzstan, Tajikistan, Turkey, Turkmenistan, Uzbekistan, Albania, and Azerbaijan).

In general, only in the $20^{\text {th }}$ century in most Islamic states family law was reformed and specific legislative acts were adopted. Nowadays, family relations in Muslim law are regulated by the law of personal status and in most Muslim states there is the special legislation that regulates either civil and family relations on the whole (the civil code), or only family relations or individual institutions of family law (special laws), they quite often contain the rules of inheritance law.

Among the basic principles of family law of Muslim states there are: justice, the principle of equality, the prohibition of discrimination, the countering of domestic violence, state protection of the family, the protection of private and personal life, welfare of the family, the best interests of the child, the upbringing of children in accordance with the norms of Islam. 
Despite the fact that in many Islamic States there has been singled out the principle of equality between men and women at the constitutional level (Article 11 of the Constitution of the Arab Republic of Egypt, Article 19 of the Constitution of Morocco, Article 46 of the Tunisian Constitution, Article 36 of the Algerian Constitution), in the majority of Islamic states there have been practical problems with its implementation, in particular, different marriage age for men and women, the institution of men's guardianship over women, polygamy, violence against women in the family. In Islamic states, a marriage contract may limit polygamy (there is the rule that a husband will no longer marry another wife), grant a woman the right to divorce without a legally specified cause, may prohibit the husband from restricting his wife's employment and traveling abroad. However, due to traditions and religious norms, women seldom make use of such possibilities in marriage contracts. Given the convergence of legal families in today's globalized world, there is an obvious need for further research into the legal regulation of family relations in Muslim states.

\section{SUMMARY}

The issue of reforming family law in Islamic states has been studied. There has been established the correlation between legislative (state) and religious regulation of family relations in Muslim states. Based on this, there have been identified three groups of states, namely: states where family relations are regulated by laws and norms of Islam, but the latter are given priority, including in the administration of justice; states where Islam is not recognized as a state religion but is widely used in the regulation of family relations; states where the majority of population are Muslims but family relations are regulated solely by law.

It has been found out that at present family relations in Muslim law are regulated by the personal status law and in most Muslim states there is special legislation that regulates either civil and family relations in general (the Civil Code), or only family relations or individual institutions of family law (special laws), such laws quite commonly contain the rules of inheritance law.

It has been analyzed what principles were formed during the reforming of family law in Islamic states. It has been found out that among the basic principles of family law of the Muslim states there are the following: justice, the principle of equality, the prohibition of discrimination, the countering of domestic violence, the protection of the family, the protection of private and personal life, the well-being of the family, the best interests of the child, the upbringing of children according to the norms of Islam.

Although the principle of equality between men and women is singled out at the constitutional level in a number of states, in the vast majority of Islamic states there are practical problems with its implementation, particularly, different marriage age for men and women, the establishment 
of the institution of men's guardship over women, polygamy, violence against women in the family. Among Muslim states, polygamy is banned only in Tunisia and Turkey.

It has been determined that in Islamic states in a marriage contract polygamy can be limited (there is the rule that the husband will not marry another woman), the woman is granted the right to divorce without the reasons stipulated by law, the husband cannot prohibit his wife from working and travelling abroad. Nevertheless, owing to traditions and religious norms, women rarely take advantage of such opportunities in marriage contracts.

\section{REFERENCES}

1. Aayesha Rafiq. Child Custody in Classical Islamic Law and Laws of Contemporary Muslim World (An Analysis). International Journal of Humanities and Social Science. Vol. 4 No. 5, March 2014. P. 267-277.

2. Нахла Юсеф, Особливості правової культури країн Близького Сходу. Політичний менеджмент. 2009. № 1. С. 147-151.

3. Вороніна М. А. Взаємодія традиційного права країн Африки 3 ісламським правом. Державне будівництво та місцеве самоврядування. 2012. Випуск 24. С. 50-62.

4. Володимир Кушніренко. Ісламське суспільство та його вестернізація. Політичний менеджмент. 2003. № 1. С. 136-141.

5. Лубський B.I., Горбаченко Т.Г., Лубська М.В. Мусульманське сімейне право: релігієзнавчо-правовий контекст. Одеса.: «Інтерпринт», 2010. $410 \mathrm{c}$.

6. Kristen Stilt, Salma Waheedi, Swathi Gandhavadi Griffin. The Ambitions of Muslim Family Law Reform. Harvard Journal of Law \& Gender. 2018. Vol. 41. P. 301-342.

7. Lama Abu-Odeh. Modernizing Muslim Family Law: The Case of Egypt. Vanderbilt Journal of Transnational Law. 2004. VOL. 37:1043. P. 1043-1146.

8. Zainah Anwar and Jana S. Rumminger, Justice and Equality in Muslim Family Laws: Challenges, Possibilities and Strategies for Reform. Wash. \& LeeL. 2007. 64. P. 1529-1549.

9. Mounira M. Charrad. Tunisia at the Forefront of the Arab World: Two Waves of Gender Legislation. WASH. \& LEE L. REV. 2007. 64. P. 1513-1527.

10. Javaid Rehman. The Sharia, Islamic Family Laws and International Human Rights Law: Examining the Theory and Practice of Polygamy and Talaq. International Journal of Law, Policy and the Family. 2007, 21. P. 108-127. doi:10.1093/lawfam/ebl023.

11. Khedher, Rayed. Tracing the Development of the Tunisian 1956 Code of Personal Status. Journal of International Women's Studies. 2017. 18 (4). P. 30-37. 
12. Чепульченко Т.О. Особливості правового регулювання в країнах релігійного права. Вісник НТУУ «КПІ». Політологія. Соціологія. Право. Випуск 1(21). 2014. С. 115-120.

13. Лубська М.В. Загальні аспекти реформування мусульманського шлюбно-сімейного права у контексті визнання правового статусу особи в державах ісламської традиції. Вісник НАУ. Серія: Філософія. Культурологія. 2010. № 2 (12). С. 126-129.

14. Haider Nadya. Islamic Legal Reform: The Case of Pakistan and Family Law. Yale Journal of Law \& Feminism. 2000. Vol. 12: Iss. 2, p. 287-341.

15. Camilo Gómez-Rivas. Women, Shari‘a, and Personal Status Law Reform in Egypt after the Revolution. October 1, 2011. URL: https://www.mei.edu/publications/women-sharia-and-personal-status-lawreform-egypt-after-revolution.

16. Samia El Nagar, Liv Tønnessen. Family law reform in Sudan: Competing claims for gender justice between sharia and women's human rights. CMI report, number 5, December, 2017. URL: https://www.cmi.no/ publications/file/6401-family-law-reform-in.

17. Best Practices. Progressive Family Laws in Muslim Countries. August 2005. p. 8. URL: https://www.wilsoncenter.org/sites/default/files/ Best\%20Practices\%20\%28English\%29.pdf.

18. What's the child marriage rate? How big of an issue is child marriage? URL: https://www.girlsnotbrides.org/child-marriage/iran/.

19. Patrick Goodenough. Iran Won't Outlaw Marriage of Under-13 Girls, as Islamic Countries Fare Worst in Annual Gender Survey. URL: https://www.cnsnews.com/news/article/patrick-goodenough/iran-wontoutlaw -marriage-under-13-girls-islamic-countries-fare.

20. Менджул М. В. Принцип рівності та сімейне право ісламських держав. Visegrad Journal on Human Rights. 2019. № 4. Vol. 1. P. 70-75.

21. Syahril Jamil. Konstruksi Hukum Keluarga Islam Di Indonesia. Jurnal Usrah. Vol. 3. № 1, Juni 2017. P. 70.

\section{Information about the author:}

Mendzhul M. V.,

Candidate of Law Sciences, Associate Professor, Department of Civil Law and Procedure, Law Faculty, Uzhgorod National University 26, Kapitulna str., Uzhhorod, Ukraine, 88000 